\title{
The effect of vaginal cleansing performed with normal saline solution or povidone-iodine before elective caesarean section on postoperative maternal morbidity and infection: A prospective randomized controlled study
}

\author{
Derya KANZA GUL (D) \\ Department of Gynecology and Obstetrics, School of Medicine, Medipol University, Istanbul, Turkey.
}

\author{
Corresponding Author: Derya KANZA GUL \\ E-mail: deryakanza@yahoo.com
}

Submitted: 20.08.2020 Accepted: 02.10.2020

\begin{abstract}
Objective: The present study was designed to determine the effect of vaginal cleansing performed with saline solution or povidoneiodine before elective cesarean section on postpartum maternal morbidity and postoperative infection.

Patients and Methods: One hundred and eighty primiparae, awaiting elective caesarean section, were assigned into the following three groups, Group1 (saline solution vaginal cleansing for 30s, n:60); Group2 (povidone-iodine vaginal cleansing for 30s, n:60); Group3 (control group, n:60).

Results: There were statistically significant differences between the 3 groups in terms of the median values for the postoperative C-reactive protein $(\mathrm{CRP})$ and fever, and visual analogue scale (VAS) score $(\mathrm{p}<0.001)$. The median value for the postoperative CRP level was $26.5 \mathrm{mg} / \mathrm{dl}, 59.5 \mathrm{mg} / \mathrm{dl}$ and $62.3 \mathrm{mg} / \mathrm{dl}$ in the saline solution, povidone-iodine and control groups respectively. The median value for the VAS score was 3,4 and 4 ; the incidence of the patients with fever $>38^{\circ} \mathrm{C}$ was $1.7 \%, 3.4 \%$ and $10 \%$ in the saline solution, povidone-iodine and control groups, respectively.

Conclusion: Vaginal cleansing with normal saline solution or povidone-iodine before caesarean section significantly reduced postoperative pain, fever, and CRP levels. Cleansing of the vagina before cesarean section clinically reduced the number of postcaesarean wound site infections, and endometritis; however, the reduction was not statistically significant.

Keywords: Caesarean section, Maternal morbidity, Postoperative infection, Vaginal cleansing, Saline solution, Povidone-iodine
\end{abstract}

\section{INTRODUCTION}

Caesarean section is one of the most commonly performed surgical operations in the world. Postpartum infection morbidity, one of the most common complications after caesarean section, not only poses a serious problem to maternal physiological and psychological wellbeing but also imposes a significant burden to the national economy [1].

Among the causes of infectious morbidity after caesarean section are endometritis, surgical site infection (SSI) and fever. The prevalence of postnatal endometritis is $6-27 \%$. It is 10 times more common in caesarean delivery than in vaginal delivery [2]. Clinically, 5-24\% of the postnatal endometritis cases are accompanied by postoperative fever and uterine fundal tenderness and is usually treated with antibiotics administered intravenously. The major concern is that endometritis might result in bacteremia, sepsis, pelvic inflammatory disease or tubo-ovarian abscess. Although, this complication is rare, it is the cause of $0.06 \%$ of maternal mortality. Even though, the incidence of surgical site infection (SSI) after caesarean section varies from one clinic to another, it generally ranges between $2 \%$ and $19 \%$, and it usually occurs within the first week of postpartum $[2,3]$.

Most of the infections are caused by the cervicovaginal flora via ascending route [4]. Prolonged premature rupture of membranes, prolonged labor, frequent vaginal examinations and bacterial vaginosis increase the incidence of infection [5]. Today, postoperative infection cannot be eliminated completely, even if modern broad-spectrum antibiotics are administered for preoperative prophylaxis. Bacteria in the vaginal flora,

How to cite this article: Kanza Gul D. The effect of vaginal cleansing performed with normal saline solution or povidone-iodine before elective caesarean section on postoperative maternal morbidity and infection: A prospective randomized controlled study. Marmara Med J 2021;34(1):33-39. doi: $10.5472 /$ marumj. 866504 
particularly enterococci, are resistant to antibiotic cefazolin [4]. Therefore, in addition to antibiotic prophylaxis, preoperative cleansing of the vagina with povidone - iodine is a safe, inexpensive and an easy method in the elimination of bacteria and fungi, and reduces the risk of postoperative infections [6, 7]. A ten-minute preoperative cleansing of the vagina with povidone-iodine reduces not only the anaerobic Gram-positive bacilli, Gram-negative bacilli but also aerobic and anaerobic Gram-positive cocci, particularly Enterococcus [8,9].

Although, there are publications emphasizing that vaginal cleansing performed before caesarean section decreases the incidence of morbidity due to postoperative ascending infections [10-12], there are other studies stating that vaginal cleansing does not have any effect $[1,13-16]$.

In the literature, there are studies indicating that uterine and abdominal washing with normal saline during caesarean section reduces postoperative endometritis and surgical site infections $[17,18]$. Today, in Turkey, vaginal cleansing performed with normal saline solution and antiseptics like povidone-iodine before elective caesarean section is not performed routinely.

This randomized prospective study was conducted to determine the effect of vaginal cleansing performed with normal saline solution or povidone-iodine before caesarean section on postpartum maternal morbidity and postoperative infections.

\section{PATIENTS and METHODS}

The Clinical Research Ethics Committee of School of Medicine, Medipol University approved the study. The management of the university hospital where the study was conducted gave its written permission to conduct the study before the data collection phase (Reference number: 108400098-604.01.01E.1468). After the participants were informed about the purpose of the study, their written consent was obtained.

Three thousand pregnant women applied to gynecology outpatient clinic of a private hospital for childbirth between January 2019 and January 2020. Of them, 1400 were primiparous and 1600 were multiparous pregnant women.
The universe of the study was 1000 pregnant women who applied for planned caesarean delivery in this date range. Of them, 300 pregnant women underwent a primary caesarean section and 700 underwent a secondary caesarean section. One hundred and eighty primiparous pregnant women wanted to have elective caesarean section. The primary caesarean section rate was $10 \%$. The caesarean section rates in muliparous was $46 \%$ and primiparous was $17 \%$. The sample size of the study was calculated using the $G{ }^{*}$ Power (version 3.1). A literature review demonstrated that vaginal cleansing had an effect on postpartum maternal morbidity [19]. Accordingly, when the maternal morbidity was taken into consideration in determining the sample size of the study, the minimum sample size was determined as 150 people ( $\mathrm{n}=50$ for each group) (confidence interval: $95 \%$, test power: $80.9 \%$ and effect size: $\mathrm{f}=0.2586919$ ) Considering the possibility of refusals, withdrawals and/or losses in the study, it was decided to include 60 participants in each group, and then the study sample was selected.

The inclusion criteria were as follows: being between the ages of 20 and 40, being in the gestational age of 37-42 weeks, having a singleton pregnancy, undergoing elective cesarean section and absence of an active infection. The exclusion criteria were as follows: having preterm labor, premature rupture of membranes, positive bacterial vaginosis and / or group B streptococcus culture within 2 weeks before caesarean section, undergoing emergency caesarean section (due to ablatio placentae, placenta previa, chorioamnionitis, acute fetal distress, placental abnormalities, active hemorrhage), having a chronic disease (e.g. diabetes mellitus, thyroid function, hypothyroidism, cardio vascular problems), regular drug use, longterm steroid therapy, body temperature above $38^{\circ} \mathrm{C}$, severe anemia and allergic reaction to the agents used.

Randomization of the women who met the inclusion criteria $(\mathrm{n}=180)$ was carried out by simple randomization using three groups of sealed envelopes with labeled notes. The women were asked to choose one of the envelopes which were labeled Group 1 (normal saline solution vaginal cleansing for $30 \mathrm{~s}$ n:60), Group 2 (povidon-iodine vaginal cleansing for 30 s, n:60) and Group 3 (control group, n:60) (Figure 1).

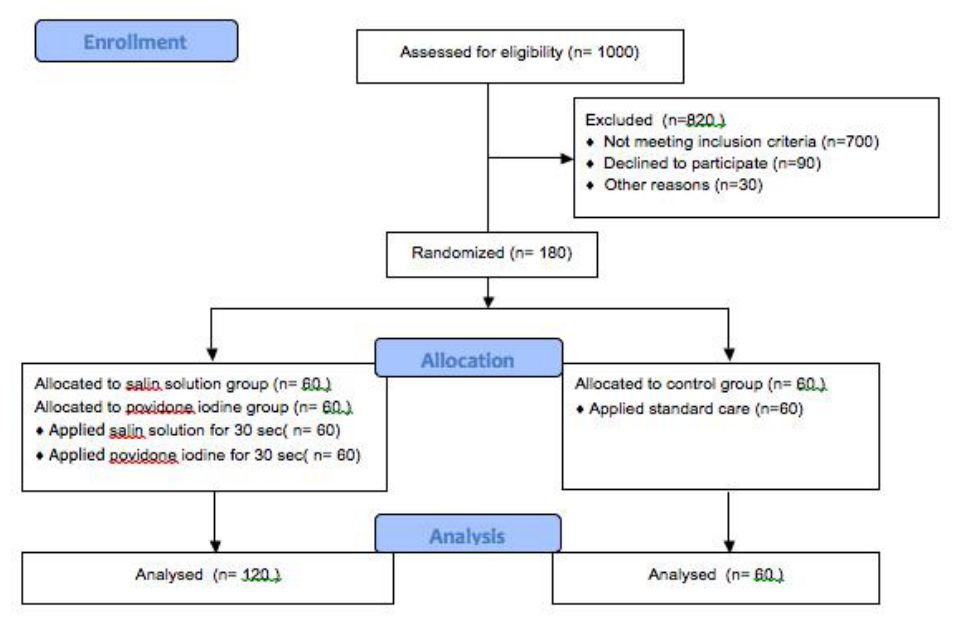

Figure 1. Randomization of participants 
All the patients were administered adequate general anesthesia and then they were catheterized with Foley's catheter under aseptic conditions. After catheterization, all the vaginal walls and fornices of the participants in Group 1 and 2 were cleaned with sterile square gauze impregnated with $50 \mathrm{ml}$ of normal saline solution or povidone-iodine solution, respectively. The cleaning agents were applied to 360 degrees of the vaginal walls and fornices by the surgical doctor for $30 \mathrm{sec}$. No vaginal cleansing solution was used for the pregnants in the control group. Skin cleansing of all the patients in the 3 groups was performed with an abdominal scrub. All the patients were given intravenous push with $2 \mathrm{~g}$ cephazolin sodium for prophylaxis at the time of umbilical cord clamping during the operation. All the patients underwent the same standard preoperative preparation, and they were operated by the same surgical team. All the participants underwent routine postoperative care.

The participants' demographic data, preoperative hemoglobin (Hgb), hematocrite (Hct), leukocyte (WBC) values, duration of surgery, postoperative $24^{\text {th }}$ hour C-reactive protein (CRP), procalcitonin (PCT) values and fever values, postoperative first week endometritis and surgical site infection findings were assessed and their postoperative $6^{\text {th }}$ and $24^{\text {th }}$ hour pain levels were assessed by the Visual Analogue Scale (VAS). Serum procalcitonin (PCT) levels were measured using an immunoluminometric assay (LUMI test PCT kit: Brahms Diagnostica, Berlin, Germany) and recorded as ng/ml. Serum CRP concentrations were assayed using a Cobas 6000 analyzer with c501 module (Roche, Switzerland) and recorded as mg/dL. VAS was developed and used by Bond and Pilowsky in 1966 for the first time [20]. VAS is a 10-cm ruler with "no pain" at one end and "worst pain" at the other end. The evaluation of VAS is defined as no pain: $0 \mathrm{~cm}$, mild pain: $0.5 \mathrm{~cm}-3.0 \mathrm{~cm}$, moderate pain: $3.5 \mathrm{~cm}-6.5 \mathrm{~cm}$, and severe pain: $7.0 \mathrm{~cm}-10.0 \mathrm{~cm}$. It is thought to be the most suitable scale for the determination of acute pain severity because it provides faster results and it is easy to understand [20].

Endometritis was defined as postoperative temperature of $>$ $38^{\circ} \mathrm{C}$ or at least twice uterine tenderness and persistent offensive lochia 24 hours after birth. Surgical infection was based on a diagnosis of erythema or wound edge separation with purulent discharge involving the caesarean incision site that requires antibiotics therapy and wound care. Postoperative febrile morbidity was defined as temperature of $38^{\circ} \mathrm{C}$ and greater after the first $24 \mathrm{~h}$ of surgery in the absence of other clinical findings suggestive of infection (chest infection, urinary tract infection, breast engorgement, etc.).

\section{Statistical Analysis}

Data were analyzed with the IBM SPSS V23. Whether the data was normally distributed was examined with the ShapiroWilk test. Kruskal Wallis test was used for the comparison of the data without normal distribution. The chi-square test was used for the analysis of the categorical data according to the groups. Analysis results were presented as a median value (min$\max$ ) for the quantitative data and frequency (percentage) for the categorical data. P-values less than 0.05 were considered statistically significant.

\section{RESULTS}

The median age of the participants varied from one group to another $(\mathrm{p}<0.001)$. There were no differences between the groups in terms of median height and weight values, and education and income levels ( $\mathrm{p}=0.513, \mathrm{p}=0.528, \mathrm{p}>0.05)$ (Tables I and II).

Table I. Comparison of parameters by groups

\begin{tabular}{|l|c|c|c|c|c|} 
& $\begin{array}{c}\text { Saline Group } \\
\text { Median } \\
(\text { min-max })\end{array}$ & $\begin{array}{c}\text { Povidone-iodine } \\
\text { Group } \\
\text { Median } \\
(\text { min-max })\end{array}$ & $\begin{array}{c}\text { Control } \\
\text { group } \\
\text { Median } \\
(\text { min-max })\end{array}$ & $\begin{array}{c}\text { Total } \\
\text { Median }^{*}\end{array}$ & p \\
\hline Age (year) & $\begin{array}{c}30.5 \\
(21-41) \mathrm{b}\end{array}$ & $\begin{array}{c}28.5 \\
(19-39) \mathrm{a}\end{array}$ & $\begin{array}{c}27 \\
(20-40) \mathrm{a}\end{array}$ & $\begin{array}{c}30 \\
(19-41)\end{array}$ & $<0.001$ \\
\hline Height:(cm) & $\begin{array}{c}162.5 \\
(157-176)\end{array}$ & $\begin{array}{c}162 \\
(150-175)\end{array}$ & $\begin{array}{c}162 \\
(155-180)\end{array}$ & $\begin{array}{c}162(150 \\
-180)\end{array}$ & 0.513 \\
\hline Weight(kg) & 78 & 80 & 76.5 & 78 & \\
\hline
\end{tabular}

$a-b$ : between the groups with the same letter, there is no difference, ${ }^{*}$ Median (min-max)

Table II. Comparison of demographic data by groups

\begin{tabular}{|c|c|c|c|c|c|}
\hline & $\begin{array}{l}\text { Saline } \\
\text { n (\%) }\end{array}$ & $\begin{array}{c}\text { Povidone- iodine } \\
\mathrm{n}(\%)\end{array}$ & $\begin{array}{l}\text { Control } \\
\text { n }(\%)\end{array}$ & $\begin{array}{l}\text { Total }{ }^{*} \\
\text { n }(\%)\end{array}$ & $\mathrm{p}$ \\
\hline Educational attainment & & & & & 0.527 \\
\hline $\begin{array}{l}\text { Literate but not a } \\
\text { graduate of any school }\end{array}$ & $2(3.3)$ & $0(0)$ & $1(1.7)$ & $3(1.7)$ & \\
\hline Primary school & $27(45)$ & $22(36.7)$ & $18(30)$ & $67(37.2)$ & \\
\hline High school & $21(35)$ & $30(50)$ & $29(48.3)$ & $80(44.4)$ & \\
\hline University & $9(15)$ & $6(10)$ & $10(16.7)$ & $25(13.9)$ & \\
\hline Postgraduate & $1(1.7)$ & $2(3.3)$ & $2(3.3)$ & $5(2.8)$ & \\
\hline Income status & & & & & 0.104 \\
\hline $\begin{array}{l}\text { Income lower than } \\
\text { expenses }\end{array}$ & $4(6.7)$ & $5(8.3)$ & $4(6.7)$ & $13(7.2)$ & \\
\hline $\begin{array}{l}\text { Income equal to } \\
\text { expenses }\end{array}$ & $\begin{array}{c}41 \\
(68.3)\end{array}$ & $49(81.7)$ & $38(63.3)$ & $128(71.1)$ & \\
\hline $\begin{array}{l}\text { Income higher than } \\
\text { expenses }\end{array}$ & $15(25)$ & $6(10)$ & $18(30)$ & $39(21.7)$ & \\
\hline
\end{tabular}

There were no statistically significant differences between the 3 groups in terms of the median values of the preoperative $\mathrm{Hgb}$, Hct and WBC, duration of surgery, values of PCT at the postoperative $24^{\text {th }}$ hour, and the VAS score for pain at the postoperative $6^{\text {th }}$ hour $(\mathrm{p}>0.05)$. There were differences between the groups in terms of their postoperative median CRP values $(\mathrm{p}<0.001)$. While the median value for the postoperative CRP level was $26.5 \mathrm{mg} / \mathrm{dL}$ in the normal saline solution group, it was $59.5 \mathrm{mg} / \mathrm{dL}$ in the povidone iodine group and $62.3 \mathrm{mg} / \mathrm{dL}$ in the control group. There were differences between the groups in terms of the VAS score for pain at the postoperative $24^{\text {th }}$ hour $(\mathrm{p}<0.001)$ (Table III). 
Table III. Comparison of laboratory and clinical parameters by groups

\begin{tabular}{|c|c|c|c|c|c|}
\hline & $\begin{array}{l}\text { Saline group } \\
\text { Median } \\
\text { (min-max) }\end{array}$ & $\begin{array}{l}\text { Povidone-iodine } \\
\text { group } \\
\text { Median } \\
\text { (min-max) }\end{array}$ & $\begin{array}{l}\text { Control group } \\
\text { Median } \\
\text { (min-max) }\end{array}$ & $\begin{array}{c}\text { Total }^{*} \\
\text { Median } \\
(\text { min-max })\end{array}$ & $\mathrm{p}$ \\
\hline $\begin{array}{l}\text { Preoperative } \\
\mathrm{Hgb}(\mathrm{g} / \mathrm{dL})\end{array}$ & $12.1(9.2-14.2)$ & $12.3(8.9-14.2)$ & $12(9.2-14.4)$ & $12.1(8.9-14.4)$ & 0.703 \\
\hline Preoperative Hct\% & $36(29-42)$ & $36.5(25.9-42)$ & $36(28-41)$ & $36(25.9-42)$ & 0.411 \\
\hline $\begin{array}{l}\text { Preoperative WBC (x } \\
\text { 109/L) }\end{array}$ & $11.4(8.8-13.8)$ & $11(7.2-17)$ & $10.2(6.1-17)$ & $11(6.1-17)$ & 0.079 \\
\hline $\begin{array}{l}\text { Postoperative } 24 \text { th hour } \\
\mathrm{CRP}(\mathrm{mg} / \mathrm{dL})\end{array}$ & $26.5(7-100) b$ & $59.5(10-170) a$ & $62.3(9-170) a$ & $46.3(7-170)$ & $<0.001$ \\
\hline $\begin{array}{l}\text { Postoperative 24th hour } \\
\text { PCT(ng/ml) }\end{array}$ & $0(0-0.3)$ & $0.1(0-0.7)$ & $0.1(0-0.5)$ & $0.1(0-0.7)$ & 0.059 \\
\hline $\begin{array}{l}\text { VAS score postoperative } \\
6 \text { thhour }\end{array}$ & $4(2-7)$ & $4(2-7)$ & $5(3-7)$ & $4(2-7)$ & 0.072 \\
\hline $\begin{array}{l}\text { VAS score postoperative } \\
24 \text { th hour }\end{array}$ & $3(1-7) b$ & $4(1-8) a$ & $4(2-9) a$ & $4(1-9)$ & $<0.001$ \\
\hline Duration of operation & $30 \min (20-60)$ & $30 \min (20-45)$ & $30 \min (25-45)$ & $30 \min (20-60)$ & 0.520 \\
\hline
\end{tabular}

$a-b$ : between the groups with the same letter, there is no difference, ${ }^{*}$ Median (min-max)

Hgb: Hemoglobin g/dL, Hct: hematocrit \%, WBC: White blood cell, CRP: C-Reactive Protein, PCT: Procalcitonin, VAS: Visual Analogue Scale (VAS).

There were no statistically differences between the three groups in terms of postoperative endometritis and wound site infection rates $(\mathrm{p}>0.05)$. The incidence of endometritis was $1.7 \%, 1.7 \%$ and $3.3 \%$ in the normal saline solution, povidone iodine and control groups, respectively. The incidence of surgical site infection was $3.3 \%, 3.3 \%$ and $6.7 \%$ in the normal saline solution, povidone-iodine and control groups, respectively. There were statistically differences between the three groups in terms of the postoperative fever levels $(\mathrm{p}<0.05)$. While the percentage of the patients with fever $>38^{\circ} \mathrm{C}$ in the normal saline solution group was $1.7 \%$, it was $3.4 \%$ in the povidone-iodine group and $10 \%$ in the control group.

Table IV. Comparison of infectious morbidity findings by groups

\begin{tabular}{lccccc} 
& $\begin{array}{c}\text { Saline } \\
\text { group } \\
\mathrm{n}(\%)\end{array}$ & $\begin{array}{c}\text { Povidone-iodine } \\
\text { group } \\
\mathrm{n}(\%)\end{array}$ & $\begin{array}{c}\text { Control } \\
\text { group } \\
\mathrm{n}(\%)\end{array}$ & $\begin{array}{c}\text { Total }^{*} \\
\mathrm{n}(\%)\end{array}$ & $\mathrm{p}$ \\
$\begin{array}{l}\text { Postoperative } \\
\text { endometritis }\end{array}$ & & & & & \\
Yes & $1(1.7)$ & $1(1.7)$ & $2(3.3)$ & $4(2.2)$ & 0.774 \\
No & $59(98.3)$ & $59(98.3)$ & $58(96.7)$ & $176(97.8)$ & \\
Postoperative & & & & & \\
$\begin{array}{l}\text { surgical site } \\
\text { infection }\end{array}$ & & & & & \\
Yes & $2(3.3)$ & $2(3.3)$ & $4(6.7)$ & $8(4.4)$ & 0.593 \\
No & $58(96.7)$ & $58(96.7)$ & $56(93.3)$ & $172(95.6)$ & \\
\hline
\end{tabular}

Postoperative

fever $>38^{\circ} \mathrm{C}$

\begin{tabular}{lcrrrr} 
Yes & $1(1.7)$ & $2(3.3)$ & $6(10)$ & $9(15)$ & $<\mathbf{0 . 0 5}$ \\
No & $59(98.3)$ & $58(96.7)$ & $54(90)$ & $51(85)$ & \\
\hline${ }^{*} \mathrm{n}(\%)$ & & & &
\end{tabular}

\section{DISCUSSION}

In the present study, the median age of the participants varied from one group to another. Except for their median age, that the three groups were similar in terms of their socio-demographic characteristics (height, weight, parity, educational attainment and income status) is important for the reliability of the study. The results of the present study are consistent with those of Göymen et al.s study [19]. In the present study, there were no statistical differences between the groups regarding the duration of surgery, preoperative Hgb, Hct and WBC values, levels of PCT at the postoperative $24^{\text {th }}$ hour, and VAS score for pain at the postoperative $6^{\text {th }}$ hour.

Although, there were statistically significant differences between the 3 groups in terms of the median values for the postoperative infection parameters CRP and fever, and VAS score for pain at the postoperative $24^{\text {th }}$ hour, the highest level of difference was observed in the normal saline solution group. The median value for the postoperative CRP level was $26.5 \mathrm{mg} /$ $\mathrm{dL}, 59.5 \mathrm{mg} / \mathrm{dL}$ and $62.3 \mathrm{mg} / \mathrm{dL}$ in the normal saline solution, povidone-iodine and control groups, respectively. The median value for the VAS score for pain at the postoperative $24^{\text {th }}$ hour was 3, 4 and 4 in the normal saline solution, povidone-iodine and control groups, respectively. The incidence of the patients with fever $>38^{\circ} \mathrm{C}$ was $1.7 \%, 3.4 \%$ and $10 \%$ in the normal saline solution, povidone iodine group and control groups. There were no statistically significant differences between the 3 groups in terms of the incidence of postoperative endometritis and wound site infections. In general, we believe that waiting for clinical diagnoses (endometritis, wound site infection, etc.) in postoperative infection detection is not an objective in assessing the effectiveness of vaginal cleansing. In our study, more sensitive parameters such as postoperative CRP levels, postoperative fever and postoperative pain were investigated. Thus, evaluation and 
early treatment can be done without having to wait for clinical symptoms.

There are publications emphasizing that vaginal cleansing performed before caesarean section decreases the incidence of morbidity due to postoperative ascending infections [10-12]; however, in other studies, it is stated that vaginal cleansing does not have any effect $[1,13-16]$.

In their meta-analysis, Haas et al., in 2018, investigated 3403 women who had vaginal cleansing with different preparations before caesarean section in terms of postoperative infection morbidity in 11 studies and found that the postpartum endometritis risk as $8.7 \%$ in the control group and $3.8 \%$ in the vaginal cleansing group (average risk ratio (RR) $0.36,95 \%$ confidence interval (CI) 0.20 to $0.63,10$ trials, 3283 women, moderate quality of evidence). On the other hand, they found no difference between the groups in terms of postoperative fever and wound site infections [10]. In their meta-analysis which included 16 studies with 4,837 women, Caissutti $\mathrm{C}$ et al., determined that precaesarean vaginal cleansing decreased the post-caesarean endometritis rate but it did not have any effect on wound site infections and postoperative fever [12]. Unlike the present study, there was a decrease in the endometritis rate in the two meta-analyses. We think that this decrease stemmed from the fact that the authors of the meta-analyses did not perform subgroup analysis and therefore they could not exclude the women with premature ruptured membranes whose active labor started.

Ylldırım $\mathrm{G}$ et al., found that vaginal cleansing before caesarean section significantly reduced post-operative endometritis risk in the povidone iodine washed group compared to the control group but there was no statistical difference between the two groups when excluding the patients with membrane rupture before delivery [1].

In another study, although, vaginal cleansing with povidone iodine before caesarean section reduced clinical postoperative fever, endometritis and surgical site infections, the difference was not statistically significant. While the postoperative endometritis rate which was $14.0 \%$ before the implementation decreased to $11.7 \%$ after the implementation ( $\mathrm{p}=0.49$, OR:0.77, CI:0.36-1.62), the postoperative fever decreased from $22.3 \%$ to $18.3 \%$ ( $\mathrm{p}=0.256$, OR:0.70, CI:0.37-1.30) . The infectious wound site complications were $4.5 \%$ and $5.8 \%$ before and after the implementation, respectively ( $\mathrm{p}=0.76$, OR:1.07, CI:0.69-3.64) [16]. These findings are consistent with those of the present study.

In some studies in which vaginal cleansing before caesarean section was performed with saline in the control group and with chlorhexidine in the experimental group, no statistically significant difference was determined in terms of postoperative endometritis $[21,22]$, which probably stemmed from the fact that they did not have a control group not undergoing vaginal cleansing but that they accepted the saline group as a control group. Guzman et al., performed vaginal cleansing with saline solution and povidone iodine before caesarean section and found that the intervention reduced the rate of post-caesarean endometritis. They also determined that the rates of postcaesarean cellulitis were similar in the two groups [23].

In the present study, in the normal saline solution group, one of the two experimental groups, normal saline solution was found to cause a significant decrease in the postoperative fever, CRP and pain levels compared to the povidone iodine and control groups. As for the postoperative endometritis and surgical site infections, although, vaginal cleansing with normal saline solution before caesarean section led to a decrease clinically, the difference was not statistically significant.

In the literature, the effects of vaginal cleansing performed before caesarean section on postoperative infectious morbidity were generally investigated without discriminating between emergency and elective caesarean section cases. However, the number of studies investigating the effect of preoperative vaginal cleansing on postoperative maternal morbidity in primiparous women undergoing elective caesarean section is limited. Similar to the present study, in their study, Göymen et al., found that in primiparous women undergoing elective caesarean section, pre-operative vaginal cleansing with povidone iodine and chlorhexidine reduced postoperative pain and that CRP values at the $24^{\text {th }}$ hour were lower [19].

Although, vaginal cleansing before caesarean section is more effective in decreasing postoperative infection morbidity in women with premature ruptured membranes whose labor started, this study also showed that vaginal cleansing performed with normal saline solution or povidone iodine solution just before birth in primiparous women undergoing elective caesarean section statistically significantly decreased postoperative pain, fever and CRP levels, which is a biochemical marker of infection, compared to the women in the control group. The beneficial effects, safety, simplicity and low cost of the intervention support its adoption as a method to reduce maternal morbidity.

\section{Strengths and Limitations of the Study}

The present study has some strengths. In order to eliminate all study biases, microbiological measurements were performed for all the participants before caesarean section, and those with infection were excluded from the study. On the other hand, the present study had some limitations as well. The size of the sample was relatively small. Another limitation was that it included only primiparous women whose active labor did not start. Therefore, we recommend that future studies should be conducted excluding these limitations.

\section{Conclusion}

In the present study, it was determined that vaginal cleansing performed with normal saline solution or povidone-iodine led to a statistically significant decrease in postoperative pain, fever and CRP levels which is a biochemical marker of infection in primiparous women undergoing elective caesarean section compared to the women in the control group. It was also determined that vaginal cleansing clinically reduced the number of post-caesarean surgical site infections and endometritis; 
however, the reduction is not statistically significant; thus, to generate statistically significant evidence on the issue, largescale studies should be performed.

\section{Compliance with the Ethical Standards}

Ethical Approval: The Clinical Research Ethics Committee of School of Medicine, Medipol University approved the study. The management of the university hospital where the study was conducted gave its written permission to conduct the study before the data collection phase (Reference number: 108400098604.01.01-E.1468).

All the procedures were performed in accordance with rules regarding studies involving human participants by taking into account the ethical standards of the institutional and/or national research committee and the 1964 Helsinki declaration and its later amendments or comparable ethical standards.

Financial Support: The author has no relevant financial information to disclose.

Conflict of Interest: The author has no potential conflicts to disclose.

Informed Consent: After the participants were informed about the purpose of the study, their written consent was obtained.

Author Contributions: D.K.G.: Project development, data collection, manuscript writing, data analysis

\section{REFERENCES}

[1] Yildirim G, Güngördük K, Asicioglu $O$, et al. Does vaginal preparation with povidoneiodine prior to caesarean delivery reduce the risk of endometritis? A randomized controlled trial. J Matern Fetal Neonatal Med 2012;25: 2316-21. doi: 10.3109/14767.058.2012.693994.

[2] Haas DM, Morgan S, Contreras K. Vaginal preparation with antiseptic solution before cesarean section for preventing postoperative infections. Cochrane Database Syst Rev 2014; 12: CD007892. doi: 10.1002/14651858.CD007892.

[3] Smaill FM, Grivell RM. Antibiotic prophylaxis versus no prophylaxis for preventing infection after cesarean section. Cochrane Database Syst Rev 2014;10:CD007482. doi: 10.1002/14651858.CD007482.

[4] Haas DM, Pazouki F, Smith RR, et al. Vaginal cleansing before cesarean delivery to reduce postoperative infectious morbidity: a randomized, controlled trial. Am J Obstet Gynecol 2010; 202: 311-16. doi: 10.1016/j.ajog.2010.01.005.

[5] Abdallah AA. Evaluation of the risk of postcesarean endometritis with preoperative vaginal preparation with povidone-iodine: a randomized controlled study. Middle East Fertil Soc J 2015;20:246-50. https://doi.org/10.1016/j. mefs.2015.03.002

[6] Hadiati DR, Hakimi M, Nurdiati DS, et al. Skin preparation for preventing infection following caesarean section. Cochrane Database Syst Rev 2014;9:CD007462. doi: 10.1002/14651858. CD007462.
[7] Berrıos-Torres SI, Umscheid CA, Bratzler DW, et al. Centers for Disease Control and Prevention guideline for the prevention of surgical site infection, 2017. JAMA Surg 2017; 152: 78491. doi: 10.1001/jamasurg.2017.0904.

[8] Amstey MS, Jones AP. Preparation of the vagina for surgery. A comparison of povidone-iodine and saline solution. JAMA 1981;245: 839-41.

[9] Asghania M, Mirblouk F, Shakiba M, Faraji M. Preoperative vaginal preparation with povidone-1odine on post-caesarean infectious morbidity. J Obstet Gynaecol 2011;3:400-3.doi: 10.3109/01443.615.2011.568644.

[10] Haas DM, Morgan S, Contreras K, Enders S, et al. Vaginal preparation with antiseptic solution before cesarean section for preventing postoperative infections. Cochrane Database Syst Rev 2018; 7: CD007892. doi: 10.1002/14651858.CD007892.

[11] Aref NK. Vaginal cleansing prior to caesarian section: To do or not to do? A randomized trial. J Gynecol Obstet Hun Reprod 2019;48: 65-8. doi: 10.1016/j.jogoh.2018.11.002.

[12] Caissutti C, Saccone G, Zullo F, et al. Vaginal cleansing before cesarean delivery: A systematic review andmetaanalysis. Obstet Gynecol 2017;130:527-38.doi: 10.1097/ AOG.000.000.0000002167.

[13] Reid VC, Hartmann KE, McMahon M, Fry EP. Vaginal preparation with povidone iodine and postcesarean infectious morbidity: a randomized controlled trial. J Obstet Gynecol 2001;97: 147-52. doi: 10.1016/s0029-7844(00)01087-5.

[14] Starr RV, Zurawski J, Ismail M. Preoperative vaginal preparation with povidone-iodine and the risk of post cesarean endometritis. J Obstet Gynecol 2005;105:1024-9. doi: 10.1097/01.AOG.000.016.4032.16599.7e.

[15] La Rosa M, Jauk V, Saade G, et al. Institutional protocols for vaginal preparation with antiseptic solution and surgical site infection rate in women undergoing cesarean delivery during labor. Obstet Gynecol 2018;2:371-6. doi: 10.1097/ AOG.000.000.0000002745.

[16] Felder L, Paternostro A, Quist-Nelson J, Baxter J and Berghella V. Implementation of vaginal cleansing prior to cesarean delivery to decrease endometritis rates. J Matern-Fetal Neonatal Med 2018;32:1997-2002. doi: 10.1080/14767.058.2017.1422717.

[17] Güngördük K, Asicioglu O, Celikkol O, Ark C, Tekırdağ AI. Does saline irrigation reduce the wound infection in caesarean delivery? J Obstet Gynecol 2010; 30: 662-6. doi: 10.3109/01443.615.2010.494206.

[18] Jafarzadeh L, Hojjati H. Effect of normal saline on cleaning uterine cavity during cesarean delivery. J Clin Diagn Res 2016;7: QC11-QC13. doi: 10.7860/JCDR/2016/17663.8151.

[19] Göymen A, Şimşek Y, Özdurak Hi, et al. Effect of vaginal cleansing on postoperative factors in elective caesarean sections: a prospective, randomised controlled trial. J Matern-Fetal Neonatal Med 2017;30:442-5.doi: 10.1080/14767.058.2016.1174995.

[20] Bond M R, Pilowsky I. Subjective assessment of pain and its relationship to the administration of analgesics in patients 
with advanced cancer. J Psychosom Res 1966;10:203-8. doi: 10.1016/0022-3999(66)90064-X

[21] Rouse DJ, Hauth JC, Andrews WW, Mills BB, Maher JE. Chlorhexidine vaginal irrigation for the prevention of peripartal infection: a placebo-controlled randomized clinical trial. Am J Obstet Gynecol 1997;176: 617-22. doi: 10.1016/ s0002-9378(97)70557-x.
[22] Sweeten KM, Eriksen NL, Blanco JD. Chlorhexidine versus sterile water vaginal wash during labor to prevent peripartum infection. Am J Obstet Gynecol 1997;176:426-30. doi: 10.1016/ s0002-9378(97)70510-6.

[23] Guzman MA, Prien SD, Blann DW. Postcesarean related infection and vaginal preparation with povidone-iodine revisited. Primary Care Update for OB/GYNS 2002;9:206-9. 